SJ Quinney College of Law, University of Utah Utah Law Digital Commons

2018

\title{
Jurisdiction-Specific Wrongful Conviction Rate Estimates: The North Carolina and Utah Examples
}

Paul Cassell

S.J. Quinney College of Law, University of Utah, paul.cassell@law.utah.edu

Follow this and additional works at: https://dc.law.utah.edu/scholarship

Part of the Criminal Law Commons, and the Criminal Procedure Commons

\section{Recommended Citation}

Cassell, Paul G., 60 Ariz. L. Rev. 891 (2018) 


\title{
JURISDICTION-SPECIFIC WRONGFUL CONVICTION RATE ESTIMATES: THE NORTH CAROLINA AND UTAH EXAMPLES
}

\author{
Paul G. Cassell ${ }^{*}$
}

Determining an error rate for wrongful convictions remains among the most pressing problems in the criminal justice literature. In a response to my earlier article, Professor George Thomas has offered an intriguing way to make that determination-through examining innocence cases uncovered through North Carolina's Innocence Inquiry Commission. This Reply reassesses Thomas's North Carolina estimate rate, concluding it to be somewhat too high. This Reply then looks at another state - my home state of Utah - to find another possible jurisdictionspecific error rate. Properly calculated, the wrongful conviction rates for North Carolina and Utah support my earlier-offered suggestion of a wrongful conviction rate in this country much lower than the rates commonly suggested in other wrongful conviction literature. This Reply underscores the important point of convergence between Thomas's estimate and my estimates: both are much lower than the conventional wisdom on the subject suggests.

\section{TABLE OF CONTENTS}

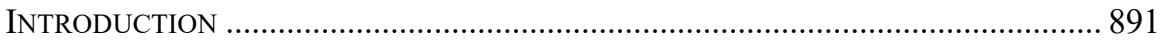

I. Recalculating George Thomas's North Carolina Estimate ...........893

II. An Estimated Wrongful CONViction RATE FOR UtAH.........................900

III. LESSONS to BE DRAWN FROM ERROR-RATE ESTIMATES ........................... 908

\section{INTRODUCTION}

Estimating the rate of wrongful convictions remains one of the most important challenges in American criminal justice. In my earlier article tackling that

* $\quad$ Ronald N. Boyce, Presidential Professor of Criminal Law and University Distinguished Professor of Law, S.J. Quinney College of Law at the University of Utah. Thanks to the editors of the Arizona Law Review for offering me the opportunity to reply to Professor Thomas's article, and to Professor Thomas himself for engaging in such an interesting and collegial exchange. This research was made possible in part through generous support from the Albert and Elaine Borchard Fund for Faculty Excellence. 
challenge, I used a methodology for calculating a wrongful conviction rate that broke the rate into component parts that could be empirically estimated. ${ }^{1}$ Using that methodology, a tentative calculation placed America's wrongful conviction rate for violent crimes somewhere in the range of $0.016 \%-0.062 \%$ - a range far below that often cited in the burgeoning innocence scholarship. ${ }^{2}$

Professor George Thomas has also tackled this important issue, although he employed a different methodology. After briefly analyzing my component-parts approach, Thomas uses what might be called a "jurisdiction-specific" approach. Thomas has calculated a wrongful conviction rate for North Carolina, relying on innocence petitions filed with the North Carolina Innocence Inquiry Commission. ${ }^{3}$ Thomas concludes that a rough estimate of North Carolina's error rate from 2007 through 2016 is $0.12 \%-0.5 \%$ - a range somewhat above mine but, again, far below that commonly recounted in the innocence scholarship. ${ }^{4}$

The editors of the Arizona Law Review have graciously invited me to reply to Professor Thomas's thoughtful article. This brief rejoinder focuses on several points.

Part I explains why Thomas's estimated figure for North Carolina's rate appears to be too high. In particular, Thomas assumes that $25 \%$ of the petitions that are filed come from factually innocent people, when a much lower figure is more plausible. Adjusting Thomas's number for this and several other reasons produces, in my view, a more accurately calculated North Carolina error rate very close to the national estimate I made in my initial article.

Part II finds another jurisdiction to explore for wrongful conviction information. While Professor Thomas was working on calculating an error rate for North Carolina, I was attempting to calculate one for my home state, Utah. While Utah lacks an innocence commission like North Carolina's, some information is available about wrongful convictions. This information suggests an error rate like the one offered in my initial article - and in my recalculation of Thomas's North Carolina error rate.

Finally, Part III draws some lessons from the error rates that appear to be extant in North Carolina and Utah. Contrary to often-advanced claims that America's wrongful conviction rates are as high as 3\%-5\%, an examination of specific jurisdictions finds error rates that are far lower - a point on which both Professor Thomas and I agree.

1. Paul G. Cassell, Overstating America's Wrongful Conviction Rate? Reassessing the Conventional Wisdom about the Prevalence of Wrongful Convictions, 60 ARIZ. L. REV. 815, 824 (2018).

2. Id. at 846

3. George C. Thomas III, Where Have All the Innocents Gone?, 60 ARIZ. L. REv. 865,866 (2018).

4. Id. at $865-66$. 


\section{ReCAlCUlating GeORge ThOMAS's NoRTh CAROLINA ESTIMATE}

How often do wrongful convictions occur? The component-parts methodology advanced in my initial article attempted to answer that important question by assembling empirically based estimates for trial error rates and the ratio of wrongful convictions in guilty pleas versus trials. ${ }^{5}$ These estimates can be debated, meaning that the ultimate calculation of the estimated error rate, derived in my initial article (about $0.016 \%-0.062 \%$ ), can also be challenged. ${ }^{6}$

An alternative approach for estimating a wrongful conviction rate is to try to find a particular jurisdiction, collect a sample of cases from that jurisdiction, and then determine the percentage of wrongful convictions contained in it. For example, one approach would be to try to develop such an error-rate estimate in a particular state or city. It might then be possible to extrapolate from that jurisdiction to the country as a whole. I have been advocating such a sampling approach for many years. $^{7}$

Against that backdrop, I was pleased to see one of America's leading criminal justice scholars, Professor George Thomas, employ this sampling methodology by taking a deep dive into the innocence data from North Carolina. ${ }^{8}$ In

5. See Cassell, supra note 1 , at 839 .

6. Thomas, for example, questions my use of the likely low wrongful conviction rates for aggravated assault, see Cassell, supra note 1, at 830-36, arguing that because aggravated assaults only rarely show up in catalogues of wrongful convictions, they should not be a major part of a wrongful conviction estimate. See Thomas, supra note 3, at 879. But my article sought to derive an estimated wrongful conviction rate for prosecution of all violent crimes reflected in the FBI Uniform Crime Reports, see Cassell, supra note 1, at 830-36, and aggravated assaults are far and away the most common violent crime. Id. at 824. Accordingly, the (low) error rate in aggravated assault cases should receive heavy weight in any generalviolent-crime error-rate estimate.

Thomas also wonders why I discuss nonstranger homicide cases, pointing out that in any homicide case - stranger or nonstranger - the victim is unavailable to identify the perpetrator. See Thomas, supra note 3, at 879 n.61. But the answer is that nonstranger homicides (many of which may be manslaughter cases) are less likely to have the conditions that lead up to a wrongful conviction. See Cassell, supra note 1, at 835-36.

7. See, e.g., Paul G. Cassell, Can We Protect the Innocent without Freeing the Guilty? Thoughts on Innocence Reforms that Avoid Harmful Tradeoffs, in WRONGFUL Convictions and the DNA Revolution: Twenty-Five Years of FreEIng the InNOCEnt 264, 271 (Daniel S. Medwed ed. 2017); Paul G. Cassell, Freeing the Guilty Without Protecting the Innocent: Some Skeptical Observations on Proposed New "Innocence" Procedures, 56 N.Y. L. Sch. L. ReV. 1063, 1082-83 (2011); Paul G. Cassell, Protecting the Innocent from False Confessions and Lost Confessions--and from Miranda, 88 J. CRIM. L. \& CRIMINOLOGY 497, 507-23 (1998) [hereinafter Protecting the Innocent].

8. Thomas previously wrote an important book on innocents and the criminal justice system. See George C. Thomas III, The Supreme Court on Trial: How the American Justice System Sacrifices Innocent Defendants (2008). In that book, he developed a back-of-the-envelope calculation of wrongful convictions. Thomas relied on a statistical model of jury decision-making and an English study of documents supporting convictions to come up with a rough estimate of a $2 \%$ error rate in the American criminal justice system. See id. at 39-40. But the relevance of the cited statistical model to real-world 
his absorbing article, Where Have All the Innocents Gone?, Thomas relies on data generated by the North Carolina Innocence Inquiry Commission. Professor Thomas notes that the Commission began hearing innocence claims in 2007. ${ }^{9}$ And in the ten years since, "out of a population of 160,000 potential claimants, and almost 2,000 claims, ${ }^{10}$ the North Carolina innocence process over ten years exonerated only ten claimants." 11 Professor Thomas then, quite reasonably, concludes that a wrongful conviction rate based on these two figures alone $(0.006 \%)$ cannot be regarded as a total figure for wrongful convictions in North Carolina during the time. ${ }^{12}$ Some allowance has to be made for innocent prisoners who either did not know about the process or lacked the cognitive ability to file an innocence claim. And even among those who had information about the process and the ability to file an innocence claim, some may have chosen not to do so for reasons such as the nearness of their release date or concern about harming their prospects for parole. ${ }^{13}$ And even among those filing claims (a total of 1,946 by Thomas's calculation ${ }^{14}$ ), further limitations exist. The Commission requires that proof of innocence be established through "credible, verifiable evidence of innocence that has not previously been presented at trial or considered at a hearing granted through post-conviction relief." 15 And Thomas also speculates that the Commission may be tilted toward rejecting innocence claims due to the presence of a prosecutor, a crime victim's advocate, and a sheriff on the Commission. ${ }^{16}$ Finally, Thomas advances the interesting reform proposal for an explicit statutory recognition of a coram nobis alternative remedy, which would make clear the State can reprosecute if it wishes. ${ }^{17}$

Of particular interest for purposes of this Reply, however, Thomas intriguingly goes on to attempt to calculate a wrongful conviction error rate in North Carolina. ${ }^{18}$ Thomas explains the importance of this effort by stating that it gives us

juries remains uncertain, see Alan E. Gelfand \& Herbert Solomon, Considerations in Building Jury Behavior Models and in Comparing Jury Schemes: An Argument in Favor of 12-Member Juries, 17 JURIMETRICS 292 (1977) (developing a model based on disagreement among jurors, not actual determination of "innocence"), and the English study measured "convictions of doubtful validity," THOMAS, supra, at 39, which are not the same thing as wrongful convictions - as the study's authors directly concede. See JOHN BALDWIN \& MichaEL MCCONVILLE, JURY TRIALS 69-70 (1979) ("[O]ur concern is not primarily with the conviction of the innocent but with the possibility that the verdict of guilty was not justified."). No doubt Thomas was aware of these limitations, leading him forward to a more viable approach for calculating a system-wide error rate.

9. Thomas, supra note 3.

10. See Lindsey G. Smith, N.C. InNocence InQuiry Comm'N, 2016 AnNuAL REPORT 5 (2017), http://innocencecommission-nc.gov/wp-content/uploads/2017/07/2016annual-report.pdf.

11. Id.; Thomas, supra note 3 , at 871 .

12. Thomas, supra note 3 , at 871 .

13. See id. at 875 .

14. There were 1,946 claims filed between January 1, 2007, and December 31, 2016, to be exact. $I d$. at 870 .

15. Id. at 883 (citing N.C. GEN. STAT. § 15A-1460(1))

16. Id. at $883-85$.

17. Id. at 888 .

18. Id. at 876 . 


\section{8] WRONGFUL CONVICTION ESTIMATES}

some sense of the number of innocent people passing through North Carolina's prisons. ${ }^{19}$

To produce his estimate, Thomas begins with the 1,946 prisoners who filed innocence claims during his ten-year (2007-2016) study period. ${ }^{20}$ It turns out that about $20 \%$ of these claims did not involve "complete factual innocence," and another 3\% involved purely procedural claims, and so Thomas removes them to come up with a universe of potential factual-innocence claims of about 1,500 (1946 $-448 \approx 1500$ ).

Thomas then tries to estimate the number of people within the pool of those claiming innocence who were, indeed, factually innocent. ${ }^{21}$ To derive such a number, Thomas relies on the Innocence Project affiliated with Cardozo Law School, which takes only DNA cases and thus has relatively solid information about the actual innocence of prisoners seeking its assistance. The Project found that about $50 \%$ of those who seek DNA testing have their guilt confirmed, while $33 \%$ are exonerated and $17 \%$ receive inconclusive results. ${ }^{22}$ With respect to the inconclusive results, Thomas assumes that they mirror the others with test results-i.e., the same ratio of $50 \%$ guilty and $33 \%$ innocent - to come up with a total of $60 \%$ guilty in the pool claiming innocence but, of course, a residual $40 \%$ innocence rate. $^{23}$

Thomas then notes that this innocence rate is much higher than the rate estimated by Mark Godsey based on his 14 years of directing the Ohio Innocence Project. Godsey estimates that of prisoners seeking assistance from his project, about $50 \%$ will be confirmed guilty, but perhaps $5 \%$ are innocent with $45 \%$ inconclusive. Apportioning the Ohio inconclusives in the same way as he did with the Cardozo inconclusives, Thomas derives a $90 \%$ guilty rate from this Ohio estimate. Thomas then averages the Cardozo guilt figure (60\%) with the Ohio figure $(90 \%)$ to estimate that the North Carolina pool of innocence applicants was composed of $75 \%$ guilty claimants - but of course, reciprocally, $25 \%$ innocent claimants. This produces a total of 375 innocent prisoners who filed claims with the Commission $(1500 \mathrm{x}$ $25 \%)^{24}$

Thomas then returns to his earlier point that not every prisoner would file an innocence claim. ${ }^{25}$ While in a preliminary version of his article he had assumed that only half of innocent prisoners would do so, I persuaded Thomas (who has always been very willing to consider competing arguments) that $90 \%$ is a more reasonable estimate. ${ }^{26}$ Thomas originally wondered how strong the incentive was for a prisoner to file an innocence claim, given that many prisoners might actually be released from prison before the investigations of their cases were complete. But an answer to this point is that a finding of innocence is likely to produce significant

$\begin{array}{ll}\text { 19. } & I d . \text { at } 875-77 . \\ 20 . & I d . \text { at } 870-71 . \\ 21 . & I d . \text { at } 873-74 . \\ 22 . & I d . \text { at } 873 . \\ 23 . & I d . \text { at } 873-74 . \\ 24 . & I d . \text { at } 874 . \\ 25 . & I d . \\ 26 . & I d .\end{array}$


financial compensation, ${ }^{27}$ with awards of up to $\$ 750,000$ being reported. ${ }^{28}$ That sort of payoff would seemingly produce extremely strong incentives for filing claims of innocence, particularly given that the "prison grapevine" is probably highly efficient at transmitting such information. Against this backdrop, it seems more reasonable to assume that $90 \%$ of innocent people are in fact filing such a claim - a figure that Thomas has now adopted. Making an adjustment for the fact that $10 \%$ of prisoners would not have filed innocence claims produces a universe of 417 innocent people in the pool of North Carolina prisoners. Divided by an estimated prison population during the decade of his study of 160,000, Thomas comes up with an innocence rate of $0.26 \%(417 \div 160,000)$, or roughly one-quarter of $1 \%$ during the ten-year period. $^{29}$

Thomas is to be commended for tackling this important project and for the way in which he has derived his numbers. Thomas has explained in detail each of his assumptions and the grounds for them, allowing subsequent researchers to evaluate their reasonableness. It is important to note, however, that the net effect of these assumptions is to take a demonstrated pool of 10 proven-innocent people in North Carolina during a ten-year period and enlarge them into a pool of 417 assumed-innocent people. ${ }^{30}$ In other words, more than $95 \%$ of Thomas's calculated innocents rest on assumptions, not proven exonerations. Or, put another way, Thomas is assuming that, even though North Carolina has a very aggressive procedure for ferreting out wrongful convictions, that procedure is only successful less than $5 \%$ of the time.

Because of Thomas's care in laying out his assumptions, it is possible to determine what happens if we alter them in any way. My sense is that Thomas's final number-which is higher than my component-parts number (but still below that of other estimates by many other innocence scholars ${ }^{31}$ ) - is too high. Fully acknowledging the need for more data on all these issues, ${ }^{32}$ I propose some more limiting assumptions than Thomas makes, as follows.

27. N.C. Gen. STAT. § 15A-1469(i) (2017) (“A person who is determined by the three-judge panel to be innocent of all charges and against whom the charges are dismissed pursuant to this section is eligible for compensation under Article 8 of Chapter 148 of the General Statutes without obtaining a pardon of innocence from the Governor.").

28. Mark Berman, North Carolina Will Give \$750,000 Each to Two Wrongly Convicted Men Who Spent Three Decades in Prison, WASH. Post (Sept. 2, 2015), https:/www.washingtonpost.com/news/post-nation/wp/2015/09/02/north-carolina-willgive-750000-each-to-two-wrongly-convicted-men-who-spent-three-decades-inprison/?utm_term $=.60 \mathrm{e} 4 \mathrm{~b} 5 \mathrm{f} 51 \mathrm{f} 27$.

29. Thomas, supra note 3 , at 874.

30. Id. at 871 .

31. See Cassell, supra note 1, at 823 (discussing Marvin Zalman, Qualitatively Estimating the Incidences of Wrongful Convictions, 48 CRIM. L. BuLL. 221 (2012) (estimating an error rate somewhere between $0.5 \%$ and $1.0 \%)$ ); see also id. at 841-42 (discussing Samuel R. Gross et al., Rate of False Conviction of Criminal Defendants Who Are Sentenced to Death, 111 Proc. NAT'L ACAD. SCI. 7230, 7233 (2014) (discussing possible error rates somewhere between $1 \%$ and $4.1 \%$ )).

32. See id. at 846 (discussing need for more research on innocence issues). 


\section{8] WRONGFUL CONVICTION ESTIMATES}

First, as Thomas properly recognizes, a critical move in his calculation is determining what percentage of people claiming innocence are actually innocent. Based on the calculations described above, Thomas ultimately concludes that $25 \%$ of all people who filed an innocence claim with the Commission were, in fact, innocent. ${ }^{33}$ But why wouldn't the true percentage be far lower? ${ }^{34}$ Thomas does not identify any substantial disincentives for a prisoner sitting in a North Carolina prison to file such a claim. It is true that a person claiming innocence must waive attorneyclient and other privileges as a precondition to seeking relief with the Commission. ${ }^{35}$ But given that the Commission appears to only come into play after initial appeals have been exhausted, ${ }^{36}$ it is not clear how much of a restraint this waiver places on bogus claims.

It is also true that evidence of new crimes discovered during the investigation must be turned over to the appropriate prosecuting authority. ${ }^{37} \mathrm{But}$ here again, if we make the reasonable assumption that an investigation into a particular crime conducted well after the fact (and by innocence investigators) is unlikely to produce evidence of other independent crimes strong enough to support a new criminal prosecution (not to mention the interest of a prosecutor who would want to prosecute an already-incarcerated or, at least, already-convicted criminal), this would not serve as much of a constraint. On quick review of media sources, I could not find a reference to any North Carolina prisoner who had been prosecuted for a new crime as the result of information uncovered after his filing of an innocence claim.

North Carolina also lacks any other safeguard against filing false claims of innocence. For example, in a state that has a parole system, the unfavorable impression made on parole authorities might be a strong disincentive to filing a bogus "innocence" claim. ${ }^{38}$ But in 1994, North Carolina appears to have enacted a

33. Thomas, supra note 3 , at 874 .

34. One bit of possibly supportive data for this conclusion is an international comparison: the Commission receives a far higher percentage of applications than do similar commissions in Scotland and Canada. See Fiona Leverick et al., Post-Conviction Review: Questions of Innocence, Independence, and Necessity, 47 STETSON L. REV. 45, 58 (2017). One conclusion that might be drawn is that American prisoners are particularly likely to file meritless claims. However, another is that North Carolina has the highest application rate because "a number of the factors known to contribute to wrongful conviction-such as ineffective defense representation and substantial incentives offered to induce guilty pleasare particularly pervasive in the U.S." Id. A full exploration of these competing possibilities is beyond the scope of this brief Reply.

35. Thomas, supra note 3, at 884 (citing N.C. GEN. STAT. $§ 15 \mathrm{~A}-1467(\mathrm{~b})$ ); see also N.C. INNOCENCE INQUIRY COMM'N, RULES \& PROCEDURES art. 10 (2017) (evidence of guilt of other crimes discovered during investigation will be provided to prosecutor for appropriate action).

36. The statute also provides that nothing in an innocence application to the Commission will harm the convicted person's "rights to other postconviction relief." N.C. Gen. STAT. § 15A-1470 (2017).

37. N.C. Gen. Stat. § 15A-1468(a1)

38. A parole system can also create issues for prisoners with legitimate innocence claims. See Daniel S. Medwed, The Innocent Prisoner's Dilemma: Consequences of Failing to Admit Guilt at Parole Hearings, 93 IowA L. REV. 491, 516-18 (2008). 
"structured sentencing" system in which parole eligibility does not play a major role in determining release from prison. ${ }^{39}$ Accordingly, this possible constraint does not appear to be in place in North Carolina.

To be sure, a prisoner's knowledge that some objective test is going to be performed on the innocence claim could serve as something of a constraint on filing. But in this connection, Thomas is wise to observe that even of those seeking DNA testing at the Cardozo Innocence Project, about $60 \%$ turn out to be guilty. ${ }^{40}$ And for the Ohio Project — which takes a broader pool of presumably less verifiable casesthe guilty rate among those claiming innocence is estimated to be around $90 \%{ }^{41}$ Presumably prisoners in Ohio know that they have little to lose in advancing such claims (and less of a chance of being detected as liars than those seeking the help of a clinic limited to DNA claims). Of course, North Carolina is accepting all claims of innocence - not just DNA claims. ${ }^{42}$ Thus, the Ohio number seems very likely to be a closer approximation of the current reality in North Carolina than the Ohio (DNA-based) number.

Another point of adjustment is that the Commission rejected $12 \%$ of initially filed claims because prisoners failed to complete the required questionnaire. ${ }^{43}$ This pool seems particularly unlikely to contain plausibly innocent prisoners. More likely, this is a pool of guilty prisoners who have been dissuaded from proceeding further with the process by the warnings contained in the questionnaire. Thomas acknowledges that "almost all" of this group were guilty but simply includes the group in his general estimate of the number of guilty claimants. ${ }^{44}$ But because we have specific information about this group, a better approach is to treat them separately - and, like Thomas, I assume that "almost all" of this group were guilty, specifically that only $10 \%$ of this group had plausible innocence claims.

One final point of correction: Thomas's denominator is 160,000 , the number of North Carolina prisoners during the ten-year study period. But North Carolina innocence procedures are available to all people convicted of any felonynot just those incarcerated. ${ }^{45}$ Given that only about half of those convicted of a felony in North Carolina go to prison, ${ }^{46}$ the correct denominator (felony convictions during the ten-year period) would more likely be twice Thomas's number, or $320,000 .^{47}$

39. See Post-Release Supervision \& Parole Commission, N.C. DeP’T PuB. SAFETY https://www.ncdps.gov/About-DPS/Boards-Commissions/Post-Release-Supervision-ParoleCommission (last visited Sept. 6, 2018).

40. Thomas, supra note 3 , at 873.

41. Id. at 874 .

42. Because DNA technologies were widely available to law enforcement agencies by 2007 , it seems unlikely that any such possibility of DNA exoneration existed in the cases Thomas was reviewing.

43. SMITH, supra note 10 , at 11 .

44. Thomas, supra note 3, at 873-74.

45. Id. at 871 .

46. Id. at 875; $c f$. Shima Baradaran Baughman, The History of Misdemeanor Bail, 98 B.U. L. REV. 837, 844 (2018) (most people in jail are awaiting trial on misdemeanors).

47. Thomas questions this particular adjustment, arguing that for nonprisoners there is less incentive to file an innocence claim. See Thomas, supra note 3, at 876. It is true 
With these points in mind, ${ }^{48}$ it is possible to recalculate Thomas's error-rate figure as follows:

FIGURE 1: North Carolina Error Rate

1,500 plausible claims of innocence

-162 (assuming that $90 \%$ of those who failed to fill out the questionnaire lacked plausible innocence claims)

1,338 corrected number for plausible claims of innocents

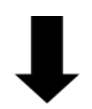

133 actual innocents in filed claims (assuming that $10 \%$ of plausible claims are in fact true)

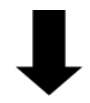

147 total actual innocents (assuming that $90 \%$ of innocents have filed claims)

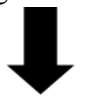

$0.045 \%$ error rate ( 147 innocents $\div 320,000$ cases).

that the automatic statutory-damages provision is triggered by a term of imprisonment in a state prison. N.C. GEN. STAT. § 148-82(a) (2017). But this provision simply provides for lostincome damages. See id. $\S 148-84$ (a). Other substantial damages are presumably available for wrongful conviction, and it is hard to see any real disincentive for filing an innocence petition given the large awards that have been obtained recently in civil-rights cases involving all manner of wrongful convictions. See Berman, supra note 28. Thomas also notes that most valid innocence claims are filed by people who have gone to prison. Thomas, supra note 3, at 875-76. But this is probably a reflection of the fact that, in a system heavily dependent on plea bargaining, someone who is factually innocent and wrongfully convicted may, paradoxically, be more likely to end up in prison than otherwise. A factually innocent person may be unable (or unwilling) to enter a guilty plea that would keep him or her out of prison.

48. While the preceding reasons have all suggested that Thomas's figure is too high, there are several reasons for thinking it may be too low. First, Thomas does not include in his calculation situations where a defendant is found guilty but succeeds in overturning the conviction on appeal. While the success on appeal might not necessarily be related to factual (as opposed to legal) innocence, it is possible that those who are factually innocent may also be able to present strong claims of legal innocence. Second, Thomas's numbers focus on a relatively recent period of time-2007-2016. But it takes factually innocent people an average of 8.8 years to prove their innocence. See Interactive Data Display, NAT'L REGISTRY EXONERATIONS (Oct. 16, 2017), https://www.law.umich.edu/special/exoneration/Pages/Exonerations-in-the-United-StatesMap.aspx. Perhaps with additional time to review this time period, Thomas might be able to begin with a larger number of proven cases of factually innocent people. I do not make any adjustment for these concerns because Thomas himself made no adjustment for them, and they may already be captured in Thomas's overall assessment of the rate of innocent people. 
This $0.045 \%$ error rate is about one-fourth of the error rate that Thomas derives. ${ }^{49}$ And, interestingly, this is an error rate that is comfortably within my originally estimated error-rate range $(0.016 \%-0.062 \%)$, derived in my initial article through other means. ${ }^{50}$ And just as Thomas presented a possible range, this single, calculated error-rate number can be converted into a plausible range of possibilities by halving and doubling the error rate to produce a range of $0.023 \%-0.090 \%$.

Finally, it is worth echoing a point that Thomas makes nicely in his article. While this estimated error rate applies only to North Carolina's state criminal justice system, there is little reason to think that error rates in other states would be significantly different. ${ }^{51}$ The procedures that North Carolina employs to adjudicate guilt are essentially the same as those employed by other states. ${ }^{52}$ And North Carolina's incarceration rate is roughly at the national average. ${ }^{53}$ Accordingly, if an error range of about $0.023 \%-0.090 \%$ exists in North Carolina, a similar error rate may well be found in other states across the country. ${ }^{54}$

\section{AN ESTIMATED WRONGFUl CONVICTION RATE FOR UTAH}

Professor Thomas's approach is intriguing because it tracks my suggestion, advanced several years earlier, that the best way to estimate an error rate is to obtain a sample of cases and then drill down into them to try to determine how many involved wrongful convictions. ${ }^{55}$ While Thomas was investigating North Carolina, I was simultaneously investigating my home state of Utah to derive a similar estimate. What does evidence from the Beehive State show?

In the 1990s, Bret Hayman and I conducted research on cases moving through the Salt Lake District Attorney's Office, the largest prosecuting office in Utah. We did not detect even a single apparent wrongful conviction in a sample of 173 filed criminal cases, ${ }^{56}$ suggesting a wrongful conviction rate below $0.57 \%$-i.e., a wrongful conviction rate of less than $1 / 173$.

I also served as a federal district court judge in Utah from 2002 to 2007. During that time, I sentenced approximately 300 men and women for federal felony offenses. The vast majority (around 98\%) of these cases involved guilty pleas, where the defendant swore under oath to guilt and defense counsel specifically represented

49. See Thomas, supra note 3, at 871 (estimating error rate of $1.2 \%$ ).

50. See Cassell, supra note 1 , at 846.

51. Thomas, supra note 3 , at $877-78$.

52. Id.

53. Id. at 878 .

54. Cf. infra notes 90-98 and accompanying text (discussing whether an estimated error rate in Utah might be comparable to that found in other states).

55. See supra note 7 (collecting citations). For an illustration of this approach in the false confessions area, see Protecting the Innocent, supra note 7, at 511 (citing to Gisli H. Gudjonsson \& Jon F. Sigurdsson, How Frequently Do False Confessions Occur?: An Empirical Study Among Prison Inmates, 1 PsYCHOL. CRIME \& L. 21, 25 (1994)).

56. See Protecting the Innocent, supra note 7, at 508 (discussing cases collected in Paul G. Cassell \& Bret S. Hayman, Police Interrogation in the 1990s: An Empirical Study of the Effects of Miranda, 43 UCLA L. REV. 839 (1996)); see also Cassell, Freeing the Guilty Without Protecting the Innocent: Some Skeptical Observations on Proposed New "Innocence" Procedures, supra note 7, at $1082 \&$ n.76. 
to me that no reason existed not to permit a guilty plea. In none of these cases (so far as I can recall) did the defendant seek to make an Alford plea. In the remaining handful of cases that went to trial and produced a conviction and sentence, it was my sense that evidence of guilt was generally overwhelming and that none of the indicators of possible wrongful conviction - i.e., shaky eyewitness testimony or cases resting only on disputed confessions - existed. I was vigilant in watching for possible cases of wrongful conviction, and following one guilty jury verdict, I even ordered a new trial where I had questions about whether the prosecution had proved the defendant's guilt beyond a reasonable doubt. ${ }^{57}$ During retrial, the federal prosecutor learned that they had (inadvertently) withheld some relevant evidence, and they immediately dismissed the case..$^{58}$

Of course, I was far from perfectly situated to detect cases in which I, as the presiding judge, would have been involved in wrongfully convicting someone. But, to my knowledge, no defendant (or defense attorney) has claimed, then or now, that I sentenced an innocent person. ${ }^{59}$ And if a figure of even a $1 \%$ wrongful conviction rate is correct, in my 300 criminal cases, there should have been about three such wrongful convictions. The fact that I didn't appear to encounter even one such alleged case leads me to think that a $1 \%$ error-rate figure must be on the high side.

It is also true that the specialized federal docket is not reflective of state criminal dockets, where most crimes are prosecuted in this country. As a result, looking to federal cases to derive a wrongful conviction estimate may skew the numbers significantly downward. Consistent with the "substructuring" point discussed at length in the wrongful conviction literature, ${ }^{60}$ many federal criminal cases involve crimes for which a wrongful conviction is not a realistic possibility. For example, almost a third of the federal docket involves immigration crimes. ${ }^{61}$ Because the mere illegal presence of the defendant is typically the only real element

57. United States v. Oetinger, No. 1:04-CR-00158-PGC, DE 47 (D. Utah Jan. 31, 2005).

58. Whether the defendant in that case was factually innocent remains unclear. He later sued the prosecutors for violating his civil rights by failing to produce exculpatory materials but was unsuccessful because he was never sentenced. See Oetinger v. Embley, No. 1:08-CV-165-CW, 2010 WL 4973324, at*1 (D. Utah Nov. 29, 2010).

59. It may be relevant to note that I have supported two clemency petitions to President Obama for defendants that I sentenced: Weldon Angelos and Joe Alvarado. Both defendants gained release. See Pamela Manson, Obama Commutes Sentences of Two Utahns Serving Time on Drug Charges, SAlt LAKe TriB. (Aug. 4, 2016, 9:04 AM), http://archive.sltrib.com/article.php?id=4190854\&itype=CMSID. But both petitions were based on the harshness of federal mandatory-minimum sentences (which I have criticized elsewhere, see Erik Luna \& Paul G. Cassell, Mandatory Minimalism, 32 CARDOZo L. Rev. 1, 4 (2010)), not on the defendant's actual innocence of the underlying crime. $C f$. Alexander Sarch \& Daniel Wodak, Resolving Judicial Dilemmas, 6 VA. J. CRIM. L. 93, 99-100 (2018) (discussing effort to obtain clemency for Angelos).

60. See Cassell, supra note 1, at 828-29; see also Thomas, supra note 3, at 879.

61. U.S. Sentencing Comm'n, Overview of Federal Criminal Cases for FisCAL YEAR 2016 at 2 fig. 2 (2017), https://www.ussc.gov/sites/default/files/pdf/researchand-publications/research-publications/2017/FY16_Overview_Federal_Criminal_Cases.pdf (29.6\% of federal cases are for "immigration" crimes). 
that the government has to prove in such cases, ${ }^{62}$ a "wrong person" situation cannot realistically develop once the defendant's identity is established. About an additional third of the federal docket is drug cases. ${ }^{63}$ Here again, for many of these cases, "wrong person" situations are not typically present, such as when a long-term federal investigation into the defendant's drug dealing establishes multiple interactions with the defendant. ${ }^{64}$

In my home state of Utah, a more generalizable assessment of a wrongful conviction rate would have to come not from Utah's federal criminal justice system, but its state system. Here in Utah, we are fortunate to have the Rocky Mountain Innocence Center ("RMIC" or "the Center"), ${ }^{65}$ an independent 501(c)(3) organization that does tremendous work to help exonerate innocent prisoners in Utah (as well as surrounding states).

The Center has been working diligently on assessing and then proving claims of factual innocence in Utah since 2000, although it is severely understaffed (it did not gain a full-time, paid employee until 2006). In the more than 16 years that the Center has been working on claims of innocence in the Utah state court system, it has proven three cases of wrongful convictions in Utah: Bruce Goodman, convicted in 1986; ${ }^{66}$ Debra Brown, convicted in 1994; and Harry Miller, convicted in $2004 .{ }^{67}$ In addition, private attorneys have obtained two factual-innocence determinations in recent years (involving two wrongful convictions dating back to 1993, Kevin Peterson and Jeb Gressman). ${ }^{68}$ That leads to a total of five apparently clear exonerations on the grounds of innocence in Utah in the last several decades.

62. See, e.g., 8 U.S.C. $§ 1326$ (1996) (criminalizing reentry by a previously removed alien, which requires proof that a previously removed alien "is at any time found in ... the United States").

63. See U.S. SENTENCING COMM'N, supra note 61.

64. See, e.g., United States v. Angelos, 345 F. Supp. 2d 1227, 1231 (D. Utah 2004).

65. Rocky MOUNTAIN INNOCENCE CTR., http://rminnocence.org (last visited Oct. $8,2017)$.

66. See Daniel S. Medwed, Innocentrism, 2008 U. ILL. L. Rev. 1549, 1563. According to the RMIC, Bruce Dallas Goodman received a stipulated Declaration of Innocence from the Court in January 2015. He also received posthumous compensation. Our Exonerees, ROCKY MOUNTAIN INNOCENCE CTR., http://rminnocence.org/ourexonerees/bruce-dallas-goodman.html (last visited Oct. 8, 2017).

67. Debra Brown, Rocky MounTAIN InNOCEnCE CTR., http://rminnocence.org/our-exonerees/debra-brown.html (last visited Oct. 8, 2017); Harry Miller, ROCKY MOUNTAIN INNOCENCE CTR., http://rminnocence.org/our-exonerees/harrymiller.html (last visited Oct. 8, 2017). I also understand that the Center also has on appeal a couple of DNA cases (about whether the standards for DNA testing have been met) and several non-DNA cases. The RMIC has narrowing criteria for the kinds of cases it will examine, such as excluding child-sex-abuse crimes (unless DNA evidence is available, or the victim has recanted) and cases in which a prisoner does not have at least seven years left on his sentence. Request Help, Rocky Mountain Innocence Ctr., http://rminnocence.org/whatwe-do/request-help.html (last visited Oct. 8, 2017).

68. Tim Gurrister, Peterson Found Factually Innocent of Child Molestation After 15-Year Term, STANDARD EXAMINER (Jan. 21, 2013), http://www.standard.net/frontpage/2013/01/21/Peterson-found-factually-innocent-of-child- 
One additional case - that of Herbert Landry — could arguably be added to this list. In 2006, Landry was convicted of aggravated arson in Utah and sentenced to five years to life in prison. The Center identified his case as one of probable innocence and secured private, pro bono counsel to represent him. ${ }^{69}$ After the trial court denied post-conviction relief, in 2016 the Utah Court of Appeals reversed, concluding that Landry had received ineffective assistance of counsel at trial. ${ }^{70}$ By that time, however, Landry had been paroled, and as the court of appeals noted, it was unclear whether a new trial "would be a reasonable use of judicial resources or even something Landry would welcome." ${ }^{\prime 1}$ On remand, the prosecutors declined to reprosecute, explaining that even if they were to retry him and again obtain a conviction, it would have been "very unlikely we would obtain any additional terms or conditions for his sentence. In other words, justice (from our view) was served and, considering the possible benefits of a retrial, our resources are better used to seek justice in the many cases we are currently prosecuting., ${ }^{, 72}$

In addition to these six cases, as of January 5, 2018, the National Registry of Exonerations lists an additional nine cases of "exonerated" people convicted of violent crimes in Utah, although the extent to which these are all factually innocent people seems dubious. ${ }^{73}$ There is one DNA exoneration on the Registry list, so that

molestation-after-15-year-term.html (Kevin Peterson); Jed Allen Gressman, NAT'L REGISTRY EXONERATIONS (Aug. 16, 2017), https://www.law.umich.edu/special/exoneration/Pages/casedetail.aspx?caseid=3264 (Jed Gressman).

69. Herbert Landry, Rocky MounTAIN INNOCENCE CTR., http://rminnocence.org/our-exonerees/herbert-landry.html (last visited July 17, 2018).

70. Landry v. State, 380 P.3d 25, 39 (Utah Ct. App. 2016).

71. Id.

72. Pam Manson, Katrina Evacueee Who was Granted New Trial on Utah Arson Charge Will not be Prosecuted Again, SAlt LAKE TriB., (Jan. 19, 2017), http://archive.sltrib.com/article.php?id=4836151\&itype=CMSID.

73. See Browse the National Registry of Exonerations, NAT'L REGISTRY EXONERATIONS, http://www.law.umich.edu/special/exoneration/Pages/browse.aspx?View $=\{$ B8342AE76520-4A32-8A06-4B326208BAF8 $\}$ \&FilterField1=State\&FilterValue1=Utah (last visited Jan. 5, 2018). In addition to those cases discussed above, the National Registry lists the following violent crime cases: Aaron Galli (convicted in 1993); Warren Hales (convicted in 2004); Jon Troy Hancock (convicted in 1993); Ted Petrossi (convicted in 1996); Paul Sheffield (convicted in 1987); Dail Stewart (convicted in 1984); Abigail Tiscareno (convicted in 2004); Conrad Truman (convicted in 2014); and Robert Weitzel (convicted in 2000). Id. While an examination of the facts of all these cases is beyond the scope of this Reply, apart from Hancock (whose estate, after his death, reached an award of $\$ 220,000$ according to the Registry) and Sheffield (who won a civil-rights case against authorities), none of the cases appear to involve clear court, or other, findings of actual innocence. Troy Jon Hancock, NAT'L REGISTRY EXONERATIONS, http://www.law.umich.edu/special/exoneration/Pages/casedetail.aspx?caseid=3274 (last visited Jan. 8, 2018); Paul Sheffield, NAT'L REgistry EXONERATIONS, http://www.law.umich.edu/special/exoneration/Pages/casedetail.aspx?caseid=4758 (last visited Jan. 8, 2018). Several of the cases appear to involve nothing more than a reversal of a conviction followed by either a retrial, in which the judge or jury entertained a reasonable doubt as to guilt - e.g., Tiscareno, Truman, and Weitzel — or a decision of the State not to retry because of concern that it might not obtain a conviction- - e.g., Hales and Petrosi. Abigail 
case can reasonably be added to the count. I am not aware of any appellate-court or post-conviction reversal on actual-innocence grounds in Utah in recent years. ${ }^{74}$ Utah's Board of Pardons and Parole has the power to pardon prisoners or commute sentences; again, I am not aware of any recent pardons on innocence grounds. ${ }^{75}$

Tiscareno, NAT'L REGISTRY EXONERATIONS, http://www.law.umich.edu/special/exoneration/Pages/casedetail.aspx?caseid=4413 (last visited Jan. 8, 2018); Conrad Truman, NAT'L Registry ExONERATions, http://www.law.umich.edu/special/exoneration/Pages/casedetail.aspx?caseid=5106 (last visited Jan. 8, 2018); Robert Weitzel, NAT'L REGISTRY ExONERATIONS, http://www.law.umich.edu/special/exoneration/Pages/casedetail.aspx?caseid=4453 (last visited Jan. 8, 2018); Warren Hales, NAT'L REgISTRY EXONERATIONS, http://www.law.umich.edu/special/exoneration/Pages/casedetail.aspx?caseid=3962 (last visited Jan. 8, 2018); Ted Petrosi, NAT'L REgistry ExONERATIONS, http://www.law.umich.edu/special/exoneration/Pages/casedetail.aspx?caseid $=4755 \quad$ (last visited Jan. 8, 2018). The Registry lists such cases as "exoneration[s]." Glossary, NAT'L REGISTRY EXONERATIONS http://www.law.umich.edu/special/exoneration/Pages/glossary.aspx (last visited Jan. 8, 2018).

Robert Weitzel's case will illustrate how questions can be raised about the factual innocence of even these "exonerated" people listed in the Registry. Weitzel was convicted of manslaughter for administering or prescribing excessive amounts of morphine to his elderly patients. Robert Weitzel, NAT'L REgISTRY EXONERATIONS, http://www.law.umich.edu/special/exoneration/Pages/casedetail.aspx?caseid=4453 (last visited Jan. 8, 2018). He was convicted at his first trial, but a new trial was ordered. State v. Weitzel, No. 991700983, 2001 WL 34048225, at*13 (Utah 2d Dist. Ct. Jan. 9, 2001). He was acquitted at the second trial. Robert Weitzel, NAT'L REGISTRY EXONERATIONS, http://www.law.umich.edu/special/exoneration/Pages/casedetail.aspx?caseid=4453 (last visited Jan. 8, 2018). Weitzel later filed a lawsuit alleging wrongful prosecution, which was dismissed. See Weitzel v. Wilson, No. 04-CV-115, 2006 WL 1409135, at*1 (D. Utah May 18, 2006). Meanwhile, federal prosecutors filed 22 counts against Weitzel for obtaining controlled substances through deception, and he pled to two of them in exchange for the remaining charges being dismissed. See Ben Fulton, Dr. Strangelove, SAlt LaKe City WKLy. (June 11, 2007), https://www.cityweekly.net/utah/dr-strangelove/Content?oid=2129145. The federal judge sentenced him to a year in prison. Angie Welling, Weitzel Gets Year in Jail Cell for Fraud, Deseret News (Sept. 12, 2002, 11:34 AM), https://www.deseretnews.com/article/936576/Weitzel-gets-year-in-jail-cell-for-fraud.html. Interestingly, 8 of the 20 dismissed charges involved Weitzel obtaining controlled substances by deception during the exact months when five of his patients died. See Fulton, supra. The extent to which this is a case of proven factual innocence seems highly debatable. See generally Dr. Robert Allen WEITZEL, MURDERPEDIA, http://murderpedia.org/male.W/w/weitzel-robert.htm (last visited Jan. 5, 2018) (listing Weitzel as a murderer and providing news articles describing circumstances of the case). Disclosure: I represented some of the victims' families in crime-victims' rights litigation in the state criminal case.

74. Cf. Gressman v. State, 323 P.3d 998, 1001 (Utah 2013) (discussing litigation by released prisoner who died during litigation to establish factual innocence).

75. The RMIC also has one other actual-innocence case pending in Utah. This case involves Michael Thompson, who was convicted in 2008 and released on an ineffective assistance of counsel claim in 2014. The State has a motion for summary judgment pending on the actual-innocence issues, but as of this writing no resolution has been reached. See Thompson v. State, No. 170901627 (Utah 3d Dist. filed Mar. 13, 2017). 


\section{8] WRONGFUL CONVICTION ESTIMATES}

Summing up these cases, we might be able to estimate about seven proven cases and another eight or so concretely alleged cases of "wrong person" convictions in Utah over the last 30 years or so (1986 to date) - only one involving a crime committed in the last decade.

If we use these figures for the numerator of an error rate, we then need to calculate a denominator - presumably the number of convictions, which we might narrow down to cases of prisoners sent to prison. One possible measure is the yearly admission rate to Utah's prison of about 3,000 prisoners per year. ${ }^{76}$ It is not clear exactly what years to include in the denominator of an innocence calculation for Utah, and arguments can be made for extending back to 1986 or perhaps pushing it forward to the last decade or so when innocence efforts became more organized in Utah. ${ }^{77}$ Interestingly, if we look at the last decade in Utah, when about 30,000 people were sent to prison, only one case of "wrongful conviction" has been alleged (simply an acquittal on a retrial, not a clearly proven case of wrongful conviction), which might suggest - consistent with the hypothesis advanced above - that wrongful convictions are declining. However, an alternative possibility is that the time required to prove a wrongful conviction has not yet occurred. ${ }^{78}$

Absolute precision is not the goal here, so we might just generously round things upward by saying that it appears that the discovered (or concretely alleged) error rate in Utah for cases of wrongful conviction involving prisoners is about 1 case every other year, with about 3,000 prison admissions a year and, if we assume Utah is similar to North Carolina, with about half of violent felons going to prison, ${ }^{79}$ another 3,000 convictions per year, producing an error rate of less than 1 in 12,000i.e., less than $0.0083 \%$.

To be sure, even using the generous measure of an "alleged" wrongful conviction that this methodology involves, several cases would likely slip through the cracks. So the estimated wrongful conviction rate needs to be adjusted upward

76. In 2013, about 3,100 prisoners were admitted to Utah's prison. E. ANN Carson, Bureau of Justice Statistics, Prisoners iN $2013 \quad 10$ tbl.9 (2014), https://www.bjs.gov/content/pub/pdf/p13.pdf. In 2014, about 2,922 were admitted, and in 2015, about 2,803 were admitted. E. ANN CARSON \& EliZABETH ANDERSON, BurEAu of Justice Statistics, PRISONERS IN 2015 11 tbl.7 (2016), https://www.bjs.gov/content/pub/pdf/p15.pdf.

77. Court procedures for exoneration through DNA were not available in Utah until 2002, and the ability to bring a non-DNA innocence claim to court became available only in 2008. See S.B. 277, 57th Leg., Gen. Sess. (Utah 2008) This might suggest starting the calculation in, say, 2008. On the other hand, in 2008, it became possible to file claims of exoneration dating back years or even decades - e.g., Debra Brown's 1986 wrongful conviction that RMIC overturned. See supra note 67 and accompanying text. This suggests an earlier starting date, although it might require other corrections.

78. See Samuel R. Gross et al., Rate of False Conviction of Criminal Defendants Who Are Sentenced to Death, 111 Proc. NAT'L ACAD. SCI. 7230, 7233-34 (2014) (discussing lengthy time to exoneration in death penalty cases).

79. See supra note 45 and accompanying text. Utah's criminal justice system has become less punitive in recent years due to a "Justice Reinvestment Initiative" designed to reduce prison populations. See Utah's Prison Population Has Dropped but Treatment Hasn't Increased Under New Justice Initiative, SAlt LAKE TrIB. (Oct. 14, 2016, 10:46 AM), http://archive.sltrib.com/article.php?id=4463953\&itype=CMSID. 
to reflect that fact, just as Thomas adjusted his North Carolina number upward to reflect undiscovered errors.

As in North Carolina, wrongfully convicted people in Utah have strong incentives to press an innocence claim. Utah has passed a law providing compensation to the wrongfully incarcerated people of about $\$ 40,000$ per year of incarceration. ${ }^{80} \mathrm{~A}$ more substantial incentive is the possibility of a civil-rights lawsuit, which can provide hundreds of thousands of dollars in damages. ${ }^{81}$ And perhaps an even more widespread incentive is Utah's strong gun culture, in which about $55 \%$ of Utah men own firearms. ${ }^{82}$ Until a felony conviction is overturned, a wrongfully convicted person is forbidden from owning a firearm. ${ }^{83}$

But even given all these facts, it seems clear that the figures recited above noticeably understate the actual number of wrongful conviction cases. Some sort of upward adjustment is appropriate. In making that upward adjustment, it is interesting to consider whether Utah's numbers would be the same as North Carolina's. Perhaps it is home-state boosterism, but my sense is that Utah's rate might be somewhat lower than North Carolina's. That sense stems from the fact that North Carolina has had several highly publicized death-row exonerations, ${ }^{84}$ which combined with other cases of clear miscarriage and led to the formation of the North Carolina Innocence Inquiry Commission discussed above. On the other hand, Utah has not had a concretely alleged case of a death-row miscarriage for the last 100 years. ${ }^{85}$ While part of the reason may be Utah's smaller population size compared to North Carolina's, another reason may be that Utah has a more robust program of indigent defense, particularly for capital cases. ${ }^{86}$

80. See UtAh Code AnN. § 78B-9-405 (West 2012).

81. See, e.g., Sheffield v. Larsen, 153 F.3d 728, 1998 WL 427085, at *1 (10th Cir. 1998) (unpublished) (reinstating Utah federal jury verdict for $\$ 300,000$ in case alleging improper actions leading to wrongful conviction).

82. Jennifer Dobner, Despite Firearm-Friendly Climate, More than Half of Utahans Don't Own a Gun, SAlt LAKE TRIB. (Apr. 8, 2017, 10:08 PM), http://archive.sltrib.com/article.php?id=5143469\&itype=CMSID.

83. $\quad 18$ U.S.C. $\S 922(\mathrm{~g})(1)(2012)$.

84. See Former Death Row Inmates Free in North Carolina, DeAth PenAlty INFO. CTR., https://deathpenaltyinfo.org/node/5950 (last visited Sept. 2, 2018).

85. Utah's last case of a concretely alleged innocent person sentenced to death is Joseph Hillstrom, a labor organizer (also known as "Wobbly") executed for murder in 1915. Jeremy Harmon, A Family Finds Place, SALT LAKE TRIB., http://local.sltrib.com/charts/joehill/morrisonsheal.html (last visited Sept. 2, 2018). The Bedau and Radelet catalogue of death-row "innocents" included Hillstrom, although their main source for the argument (distinguished author Wallace Stegner) actually believed Hillstrom was guilty. See Stephen J. Markman \& Paul G. Cassell, Protecting the Innocent: A Response to the Bedau-Radelet Study, 41 StAn. L. REV. 121, 138-39 (1988). A recent "reinvestigation" of the case was an intriguing play written by my law-school colleague, Deborah Threedy, which is inconclusive on the issue. See Barbara M. Bannon, Review: Song and Story of Joe Hill Seamlessly Coalesce in Plan-B's "One Big Union”, Salt LaKe TriB. (Nov. 15, 2016, 9:17 AM), http://archive.sltrib.com/article.php?id=4572823\&itype=CMSID. The case continues to be a controversial one, as chronicled in a lengthy series of articles by the Salt Lake Tribune on the 100th anniversary of the execution. See Harmon, supra.

86. See Paul G. Cassell, In Defense of the Death Penalty, in Debating the Death 
In light of all these points, as a final adjustment, I will increase the rate from $0.0083 \%$ - Utah's observed and concretely alleged wrongful conviction rateby fourfold $(400 \%)$ to take into account the fact that not every case of wrongful conviction produces a credible and public allegation of wrongful conviction. This is a substantial upward adjustment, going well above what are not only proven cases of wrongful conviction but also concretely alleged cases. To be sure, this adjustment can be debated. The argument can always be made, with some kernel of truth, that we do not know for certain what the relation is (in Utah or elsewhere) between discovered and alleged cases of innocence and the total number of innocents. But this Reply has tried to collect the available empirical information on the subject so that an informed estimate of that relation can be made. A $400 \%$ adjustment would appear to be a substantially greater amount than other similar adjustments that have been made by other researchers in analogous contexts, including Thomas in his article. ${ }^{87}$ Moreover, this adjustment produces an overall wrongful conviction rate of $0.033 \%^{88}$ - and a plausible range of the wrongful conviction rate, if we halve and double the figure, of $0.017 \%-0.066 \%$ - which is quite similar to the range previously calculated via the component-parts methodology and also not too far off of the revised range for Thomas's North Carolina figure calculated above ${ }^{89}$

To be clear, this Reply makes no suggestion of having definitely proven that Utah's wrongful conviction rate falls with the range of $0.017 \%-0.066 \% .{ }^{90} \mathrm{We}$ need more research on frequency of wrongful convictions, a point I have pressed elsewhere. ${ }^{91}$

Nor should this Reply be read as in any way suggesting that the efforts of the RMIC are unimportant. For each of the clients it successfully serves, the results are life-changing. Yet it would require a 30 -fold increase from the concretely alleged to the actual error rate to bring Utah's rate in line with the commonly advanced $1 \%$ overall error-range figure, or nearly a 100 -fold increase to bring Utah's rate up to the 3\% figure calculated by Risinger. Put another way, if a 3\% figure is correct, in Utah the RMIC and other private defense attorneys looking at innocence issues should have had a potential pool of about 30 wrongfully convicted people sent to prison each year (and 300 each decade) from which to work to prove innocence. It seems likely to me that the capable lawyers at the RMIC would have been able to

Penalty: The Experts from Both Sides Make Their Case 183, 209-10 (Hugo Bedau \& Paul G. Cassell eds., 2004) (noting strengths of Utah's system for appointing counsel in death penalty cases).

87. See Thomas, supra note 3, at 876-77 (noting a generous assumption that $50 \%$ of wrongfully convicted people would not file a claim); $c f$. Michael Risinger, Innocents Convicted: An Empirically Justified Factual Wrongful Conviction Rate, 97 J. CRIM. L. \& CRIMINology 761, 779 (2007) (adjusting from 3.3\% observed error rate to 5.0\% maximum estimated rate in capital-case context).

88. 4 x $0.0083 \%$.

89. See supra notes 31-54 and accompanying text.

90. Nor am I conceding the factual innocence of all the cases discussed above. I am simply assuming innocence to eliminate a possible dispute about my calculations.

91. See, e.g., Paul G. Cassell, Can We Protect the Innocent without Freeing the Guilty? Thoughts on Innocence Reforms that Avoid Harmful Trade-offs, in WrONGFUL Convictions and the DNA Revolution: Twenty-Five Years of FreEIng the InNocent 264, 271 (D. Medwed ed., 2017). 
identify far more cases to work on if that many innocent people were entering Utah's prisons each year.

Finally, it is worth briefly considering whether an error rate calculated for Utah's criminal justice system would be comparable to North Carolina's or that of other states. I have previously collected evidence that Salt Lake County's criminal justice system looks fairly similar to those in other states, although the County has somewhat lower violent crime rates than elsewhere. ${ }^{92}$ Utah's violent crime rate was lower than the national average while its property crime rate was slightly higher. ${ }^{93}$ Comparing the same measure as Thomas used for North Carolina (incarceration rate for prisoners of sentences of one year or more), Utah's rate is lower than North Carolina's and lower than the national average. ${ }^{94}$ But then again, for a state with a lower crime rate, a lower incarceration rate would be expected.

Probably the main issue to consider when extrapolating from an error rate in a particular state to the rest of the country is whether the state is unusually careful (or not) in attempting to prevent wrongful convictions. While earlier I raised a few points to suggest that Utah might have a modestly better criminal justice system than North Carolina, ${ }^{95}$ it is hard to see why Utah's error rate would be dramatically different than other states'. If so, Utah's error rate might be taken to be roughly reflective of the error rate across the country, although, as with so much else in this area, additional research on this subject is plainly warranted.

\section{LESSONS TO BE DRAWN FROM ERROR-RATE ESTIMATES}

In concluding this brief Reply, it may be useful to summarize what can be learned from these estimates about possible wrongful conviction rates as part of a broader discussion of the problem of wrongful convictions.

In my initial article, I suggested that a reasonable estimate of the wrongful conviction rate for violent crimes in the United States might be somewhere in the range of $0.016 \%-0.062 \% .{ }^{96}$ In his article, Professor Thomas provided an estimate from North Carolina of a felony error rate of $0.125 \%-0.500 \% .{ }^{97}$ I adjusted his figure to come up with, in my view, a more plausible range in North Carolina of $0.023 \%$ $0.090 \% .^{98}$ And I estimated that an error rate for Utah might be approximately $0.017 \%-0.066 \%{ }^{99}$

92. See Paul G. Cassell \& Bret S. Hayman, Police Interrogation in the 1990s: An Empirical Study of the Effects of Miranda, 43 UCLA L. REV. 839, 850-51 (1996).

93. See Crime in the United States by State, 2011, FBI, https://ucr.fbi.gov/crimein-the-u.s/2011/crime-in-the-u.s.-2011/tables/table-5 (last visited Jan. 5, 2018). Thomas used 2011 as the date for his comparison, and so for this easily accessible figure, I used 2011 as well.

94. E. Ann Carson, Bureau of Justice Statistics, Prisoners in 20169 tbl.7 (2018), https://www.bjs.gov/content/pub/pdf/p16.pdf.

95. See supra notes 80-86 and accompanying text.

96. See Cassell, supra note 1, at 846.

97. See Thomas, supra note 3 , at 880 .

98. See supra notes 48-54 and accompanying text.

99. See supra notes 87-91 and accompanying text. 


\section{8] WRONGFUL CONVICTION ESTIMATES}

What to make of these numbers? As Thomas does, it may be useful for me to begin by underscoring a very important point of convergence between us. Regardless of whether one agrees with Thomas's error-rate estimate or one of my three estimates, all these estimates are, as Thomas points out, "substantially lower than [wrongful conviction] researchers have generally believed." 100 Other scholars writing in the area have reached conclusions about error rates that are less grounded in empirical evidence than are Thomas's and mine. While our methodologies are far from perfect - and we both have called for further research in the area - perhaps the convergence of our estimates as producing plausible ranges below those of our researchers may be grounds for reevaluating and adjusting downward the current conventional wisdom on the subject.

Our lower figures are also important because, as Thomas again points out, they may suggest a need for caution before embracing far-reaching or untested innocence reforms. ${ }^{101}$ Many proposals by innocence scholars produce tradeoffs between convicting the innocent and freeing the guilty. ${ }^{102}$ Any realistic assessment of these tradeoffs will require evaluating the weights to be attached to competing sides of the scales. Both Thomas and I are concerned that insufficient attention might have been paid to properly calibrating the tradeoffs involved in some reform measures through possibly overestimating the number of innocents who might benefit.

One point of slight divergence between our approaches is the somewhat different ranges that they produce. While Thomas comes up with a North Carolina error range of $0.125 \%-0.500 \%$, my readjusted North Carolina range is $0.023 \%-$ $0.090 \%$ - with my highest error rate falling somewhat below Thomas's lowest rate. ${ }^{103}$ While readers will reach their own conclusions about who has the better of the arguments over North Carolina in particular, it seems fair to point out a convergence between my three separate efforts to calculate an error range. The three ranges that I derived - the national component-parts range of $0.016 \%-0.062 \%$, the adjusted North Carolina range of $0.023 \%-0.090 \%$, and the estimated Utah range of $0.017 \%-0.066 \%$ - are all largely overlapping. This conjunction of three different approaches all leading to the same conclusion seems to provide some support for my estimates in preference to Thomas's.

Returning to another theme of convergence between Thomas and me, we both agree that the wrongful conviction rate in this country today is noticeably lower than it was several decades ago. ${ }^{104}$ I developed this point at length in my initial article, suggesting that it is reasonable to believe that whatever the wrongful conviction rate was in the 1980 s, for example, it might be about half of that today. ${ }^{105}$ As noted above, evidence from Utah may support a similar conclusion. ${ }^{106}$

100. Thomas, supra note 3 , at 880 .

101. Id.

102. Cassell, supra note 1 , at 854 .

103. Compare Thomas, supra note 3 , at 880 , with supra notes $48-54$ and accompanying text.

104. Thomas, supra note 3 , at 879 .

105. Cassell, supra note 1, at 836-37.

106. See supra note 62 and accompanying text. One other small bit of data that may 
Thomas concurs with the sentiment of progress in the criminal justice system but contends that an estimate of 50\% improvement is overly optimistic. ${ }^{107}$ But it may actually be too pessimistic. In a variety of ways, advances in technology are now making it possible for people to prove their factual innocence in ways that were never possible before. For example, progressing technologies with cellphonetracking data and Fitbit trackers can provide substantial proof of innocence by confirming an alibi for people who might otherwise fall under suspicion. ${ }^{108}$ As Professor Fairfield and Luna argue in an important recent article, Digital Innocence, the "depth and breadth of corporate and government surveillance virtually guarantee that evidence of digital innocence will be found using the tools of Big Data." 109 None of this means that the problem of wrongful convictions will disappear in the future. But it does seem likely that, just as in many other areas of human endeavor-e.g., medical science, computing technology, vehicle safety - things are improving.

In light of Thomas's acknowledgment of recent improvements in the system, I have to question whether it is useful to look at cases from decades past as emblematic of America's current criminal justice system. For example, Professor Thomas's article begins and ends with the heartbreaking story of Henry McCollum, a person with an intellectual disability ${ }^{110}$ who was wrongfully convicted in 1983 for the rape and murder of an 11-year-old girl based on a flimsy false confession. ${ }^{11}$ McCollum had no significant history of prior crimes. ${ }^{112}$ He simply fell under suspicion for being at the wrong place at the wrong time, suffering a terrible injustice. But while McCollum's case is tragic, Thomas does not build an argument that McCollum's conviction 35 years ago is representative of wrongful conviction cases in North Carolina (or elsewhere) today. ${ }^{113}$

bear on this subject is that "acquittal" rates in federal courts have declined over time. See Ronald F. Wright, Trial Distortion and the End of Innocence in Federal Criminal Justice, 154 U. PA. L. REV. 79, 102 (2005). However, this appears to be due to changes in federalcharging practices and other factors rather than some indication of fewer innocent people in the federal system.

107. Thomas, supra note 3 , at 879 .

108. See, e.g., Kate Briquelet, Fitbit Could Prove a Man's Innocence. Google Could Send Another to Prison for Murder., Daily Beast (Feb. 27, 2018, 5:04 AM), https://www.thedailybeast.com/fitbit-could-prove-a-mans-innocence-google-could-sendanother-to-prison-for-murder.

109. Joshua A.T. Fairfield \& Erik Luna, Digital Innocence, 99 CoRnELl L. REV. 981, 1076 (2012).

110. In some of my older writings, I have used the term "mental retardation" to describe with precision and call attention to the medical condition that McCollum and others similarly situated have. Recently, the term "intellectual disability" has replaced that term, and so I use it here. See, e.g., Change in Terminology: "Mental Retardation" to "Intellectual Disability", 78 Fed. Reg. 46499-01 (Aug. 1, 2013) (Social Security Administration change in listing of impairments).

111. See Thomas, supra note 3, at 867-69, 887-88.

112. State v. McCollum, 433 S.E.2d 144, 161 (1993).

113. Given considerable improvements in the way in which the criminal justice system considers false confession claims today, see Cassell, supra note 1 , at 838 , it seems unlikely that McCollum would be convicted today. $C f$. Matthew Tokson, Knowledge and Fourth Amendment Privacy, 111 Nw. U.L. Rev. 139, 164-65 (2016) (discussing advancing 


\section{8] WRONGFUL CONVICTION ESTIMATES}

Perhaps a more typical case of an erroneous conviction in North Carolina is one that I discuss in my initial article: the case of Robert Wilcoxson. ${ }^{114}$ His is one of the cases that falls squarely within Thomas's sample, as he pled guilty to seconddegree murder in 2002, and the North Carolina Innocence Inquiry Commission found him to be factually innocent of a drug-related murder in 2011. ${ }^{115}$ But the reason that Wilcoxson initially fell under suspicion was because he was an armed drug dealer making tens of thousands of dollars in drug trafficking at the time of the homicide. Thereafter, rather than go to trial on the matter - or attempt an Alford or no-contest plea to the charges-Wilcoxson entered a guilty plea, swearing under oath before the presiding judge that he was guilty of the killing. ${ }^{116}$

The Wilcoxson story is obviously less poignant than McCollum's because Wilcoxson was not as free of criminal culpability as McCollum. But, as I explain in my initial article, Wilcoxson's wrongful conviction seems to be more typical of contemporary wrongful conviction cases. Most of those wrongfully convicted in recent years apparently have a prior criminal record ${ }^{117}$ suggesting that this is a substantial contributing factor to wrongful convictions - one that is rarely discussed in the innocence literature. Focusing on cases like Wilcoxson's may suggest the importance of different remedies to help prevent wrongful convictions. States may wish to consider, for example, making Alford pleas more generally available for people who maintain that they are factually innocent.

In sum, Professor Thomas wonders, in the title of his article, "Where Have All the Innocents Gone?" A partial answer appears to be that, to a large extent, they were never there to begin with. While innocence scholars have sometimes asserted a factual wrongful conviction rate of $3 \%-5 \%$, such estimates appear to be far too high. Thomas himself used to think that the error rate was higher than $1 \% .{ }^{118}$ But based on the evidence he has collected, Thomas has rethought his earlier view. Perhaps his thoughtful approach to the issue - along with the estimates that he and I have reached in our articles - will lead others to reevaluate their assessments of this important question.

technology and the law).

114. See Cassell, supra note 1, at 847-49; see also State v. Kagonyera/Wilcoxson, N.C. INNOCENCE INQUIRY COMM'N, http://innocencecommission-nc.gov/cases/state-vkagonyera-wilcoxson/ (last visited Sept. 2, 2018).

115. See State v. Kagonyera, No. 00CRS56086, 2011 WL 8472667 (N.C. Sup. Ct., Sept. 22, 2011).

116. See Cassell, supra note 1, at 848-49.

117. See id. at 837-38.

118. Thomas, supra note 3 , at 880 . 